this transaction have had an op-p possession of the part, never reportunity of publishing their state- lapsing into himself, or trying to ments as well as the rich man raise a langh by trickery or burhis ; and, knowing as we do, the lesque, and giving all the more infamous treatment that these in- quiet parts of the dialogue in a jured individuals have received from some of the partisans of the Rev. Doctor, we should have been guilty of a double act of injustice, had we withheld from the world their exculpatory depositions. natural and unforced manner, which is rarely to be perceived on the stage. In the more trying passages he gave a picture of remorse working in a long.seared conscience, and agitating an uncultivated but powerful mind, which was no less than terrific. His vain attempts to assume the THE DRAMA. appearance of indifference; the half-stifled utterance with the

Covent-Garden Theatre.OnWednesday night Mr. Rayner, who has played rustic characters at the English Opera House with considerable success, made his first appearance at this theatre, as Tyke in the School of Reform. The deep impression left on the public mind by the admirable performance of Emery, made this attempt arduous, but we are happy to say that it was completely successful. Except that Mr. Rayner wants some of the personal advantages which Emery possessed for representing the stout-hearted ruffian, we do not think his performance at all inferior to that which we were accustomed to regard as the perfection of rude tragedy. From first to last he retained entire "climbing passion" forced; his frightfully vivid description of his old father falling down lifeless as he saw him conveyed to the ship, and, perhaps, above all, the interview with his father, where the old affection quivers on his lips and dissolves him in welcome tears, were so powerful and true, that we almost hesitate to call them acting. The audience not only testified their sense of his excellence in the principal scenes by lond applauses, but by the still more unequivocal testimony of tears, and by the deep silence which they kept whenever he appeared towards the close of the play. The other parts were acted better than they deserved, for more inane vérbiage and sickening 
zant were never, perhaps, com- never been successfully intropressed into the same space than that which the author has distributed among them. Blanchard and Mrs. Gibbs, however, produced some amusement, in spite of the dialogue. At the close of the play, Mr. Abbott came forward to announce the performances for the next night; but his voice was drowned in applause and cries for "Rayner." He persisted, however, in the execution of his task, but the call was renewed when he retired; and after some very becoming hesitation, $\mathbf{M r}$. Rayner appeared, evidently much affected, and announced that, "with the kind approval of the audience, the play would be repeated on Friday," and retired amidst the cheers of the house. It is really gratifying to record success so genuine, and so fairly earned; and to perceive a line of character where so much excellence was lately displayed filled again by a real and an original actor.

After the play, a melodrame was produed, under the flaring title of the "Beacon of Liberty." It is founded on the history of the deliverance of Switzerland by William Tell, which forms the subject of one of the noblest German tragedies, but which has duced on the English stage. The production of last night is incumbered by an underplot, of which Miss Love is the heroine, as if a great revolution were not a subject broad enough for an afterpiece; and the story, simple and beautiful in itself, is perplexed by the introduction of a number of agents, whose motives and fortnues we neither can nor wish to follow. The single scenes where Tell obeys the mandate of the Governor, and shoots an apple on the head of his son, produced considerable effect, but all the rest was tiresome in the extreme. It is hardly possible to lescribe the language, except by saying that it seems taken from the lowest order of school themes on liberty, or the most Irish of after-dinner orations. We were at first a little surprised, that in the present state of the police, a drama containing such bold invectives on the petty creatures of power should have passed the Lord Chamberlain's Office; but we soon perceived the wisdom of those who allowed it to pass in the contempt it tended to throw on the sentiments which it was designed to honour. There was one ludicrous hit: the Govermor's hat is stuck upon a poll for the people to re- 
verence, and one of the officer's replies to the scruples of his comrade, as to the reasonableness of the exaction, "Don't we often bow to a hat that has as little in it ?" which was greatly relished by the audience. Mr. Bennett played William Tell; some of his silent acting was very good, but he marred its effects when he spoke with intolerable mouthing. Miss Foote had little to do as the wife of the hero, but she played with feeling. The music by Bishop was not very new, and except one pretty duet, sung by Master Longhurst and Miss R. Boden, does not require notice. There was some well painted Swiss scenery; but disapprobation was expressed repeatedly in the course of the piece, and it was finally announced for repetition by $\mathbf{M r}$. Abbott, amidst contending hisses and applauses.

D-ery-Lane. - The Comedy of $A$ Trip to Scarborough was on Thursday night repeated with great applause. Mr. Browne, as Lord Foppington, confirmed, if he did not heighten, the good opinion which had been previously formed of his talents in this line of acting. Some disparaging remarks have been made on his pronouncing Tom, Tam-Stop, Stap, \&c. but this, if it be objectionable, origi- nates not with him. It was by no means uncommon for Authors, towards the close of the last century but one, to take this mode of ridiculing the fops of their day; an awkward mode perhaps, but still one which an actor ought to respect, as it is certainly erring (if there be any error) on the right side, to adhere too closely to the text of his Author. It is a peculiarity of which we have not often to complain. Miss Воoтr was again most successful in Miss Hoyden. She convulsed the house with laughter, and won the loudest testimonials of universal approbation.

\section{MEDICAL EXTRACTS.}

OrGaNs in the animal economy cannot long be so deranged as to produce vitiated secretions, without at the same time giving rise to other deviations from health. The debility of stomach which prevents a due secretion of healthy gastric fluid, must at length produce some of those other effects which are witnessed in disorders of this organ.

The symptoms which arise immediately from undigested food, exist in various degrees in different cases. People frequently 